\title{
An Environmentally Benign Synthesis of 2-Cyanomethyl-4-phenylthiazoles under Focused Microwave Irradiation
}

\author{
Todor Deligeorgiev ${ }^{1 *}$, Stefka Kaloyanova ${ }^{1}$, Nedyalko Lesev ${ }^{1}$, Ramón Alajarín ${ }^{2}$, Juan J. Vaquero ${ }^{2}$, \\ Julio Álvarez-Builla ${ }^{2}$ \\ ${ }^{1}$ Faculty of Chemistry, University of Sofia, Sofia, Bulgaria \\ ${ }^{2}$ Department of Organic Chemistry, Faculty of Pharmacy, University of Alcala, Madrid, Spain \\ E-mail: toddel@chem.uni-sofia.bg \\ Received July 18, 2011; revised August 29, 2011; accepted September 15, 2011
}

\begin{abstract}
An improved environmentally benign procedure for synthesis of substituted 2-cyanomethyl-4-phenylthiazoles under focused microwave irradiation using glycerol as solvent has been carried out. The method allows the synthesis of products in excellent yields with short reaction times and the work-up is easy. This approach can be applied to the preparation of a variety of derivatives.
\end{abstract}

Keywords: 2-Cyanomethyl-4-phenylthiazoles, Microwave Synthesis, Glycerol, Green Chemistry

\section{Introduction}

An important problem that faces organic chemists today is the development and improvement of methods for the synthesis of compounds with specific desired properties. Single-step syntheses are advantageous since they simplify known synthetic procedures for the preparation of intermediates and the reaction time can be reduced through various improvements, such as the use of environmentally friendly conditions and energy sources. 2-Hetarylacetonitriles are versatile reagents that have been extensively utilized in heterocyclic synthesis. Recently, interest in the synthesis of 2-thiazolyl-substituted pyrroles has increased due to the discovery of highly efficient enzyme inhibitors among the 2-thiazolylpyrroles derivatives [1,2]. Several 3-(1,3-thiazol-2-yl)pyridine-2(1H)- ones have been found to act as selective $\mathrm{GABA}_{\mathrm{A}}(\gamma$-aminobutyric acid) antagonists and anxiolytics $[3,4]$.

2-Hetarylacetonitriles are important intermediates for the synthesis of compounds that are useful in the treatment and/or prevention of neuronal disorders, neurodegenerative or inflammatory diseases, and cancer or metabolic disorders [5-7]. Highly efficient inhibitors of some enzymes are derivatives of thiazolyl-substituted pyrrols [8]. 2-cyanomethylthiazoles are very valuable dye intermediates for the synthesis of fluorescent coumarins, suitable as laser dyes or as fluorescent covalent probes for labeling of oligonucleotides with very high fluorescence quantum yield (approximately 1) [9-13].

Many reactions have been developed in recent years that involve the synthetic potential of 2-hetarylacetonitriles toward electrophiles [14-16]. One of the most commonly used procedures for the synthesis of the thiazole ring is based on the Hantzsch reaction (the reaction of $\alpha$ halo ketones with thioamides), which proceeds by heating the reaction components in ethanol and gives the target compounds in good yields $[12,17]$. However, 2methyl-4-phenylthiazole can only be prepared by heating $\alpha$-bromoacetophenone with thioacetamide in anhydrous ethanol in the presence of gaseous hydrogen chloride for prolonged periods [18].

In the work described here we aimed to develop a highly efficient and reproducible procedure for the synthesis of substituted 2-cyanomethyl-4-phenylthiazoles under focused microwave irradiation using glycerol as solvent, which is widely recognized as an eco-friendly solvent in organic chemistry [19-21].

\section{Experimental}

All products were characterized and/or compared with reported data. Melting points were obtained on a Gallenkamp apparatus and are uncorrected. ${ }^{1} \mathrm{H}-\mathrm{NMR}$ spectra of the compounds not reported previously were recorded on Varian $200 \mathrm{MHz}$ and Bruker Avance $250 \mathrm{MHz}$ spec- 
trometers in $\mathrm{CDCl}_{3}$ as solvent. The HPLC-MS technique in experiments for the optimization of reaction conditions was carried out on an Agilent HP1100 system. Elemental analyses were performed on a Vario III instrument. All microwave irradiation experiments described herein were performed using a single-mode Initiator 2.5 equipment from Biotage $\mathrm{AB}$ using standard Pyrex sealed vessels (capacity $2 \mathrm{~mL}-5 \mathrm{~mL}$ ). Experiments were performed in power-control mode where the temperature was monitored using the built-in calibrated IR sensor. Vessels can be operated at temperatures up to $250^{\circ} \mathrm{C}$ and a pressure of 20 bar (pressure is not monitored). The vessel has been introduced in the microwave cavity of the Initiator 2.5 equipment and covered with a safety lid. The progress of the reactions was monitored by TLC (Merck F 254 silica gel; dichloromethane:hexane, 6:1). All starting materials and solvents were commercial products from Sigma-Aldrich. The products that have not been reported previously were characterized by ${ }^{1} \mathrm{H}-\mathrm{NMR}$ spectroscopy and elemental analysis. Analytically pure samples of the reaction products were obtained by recrystallization from ethanol.

\subsection{General Procedure for Preparation of Compounds 3a-3j in Biotage Microwave System}

2-Cyanothioacetamide (1) $(0.001 \mathrm{~mol})$ and the appropriate substituted 2-bromoacetophenone (2a-j) (0.001 mol) were mixed in a $2 \mathrm{~mL}-5 \mathrm{~mL}$ microwave vial with anhydrous glycerol $(3 \mathrm{~mL}-4 \mathrm{~mL})$. The reaction mixture was prestirred for $4 \mathrm{~min}$ and irradiated at 40 - 45 Watts for a time ranging between $3.5 \mathrm{~min}$ and $4.5 \mathrm{~min}$ (Table 2 ). The product (3a-3j) was dissolved in ethanol (1 mL - $2 \mathrm{~mL}$ ) and precipitated by dilution with water $(50 \mathrm{~mL})$. The resulting solid was filtered off and air dried.

\subsection{Characterization Data for the Thiazolylacetonitriles $3 \mathbf{a}-\mathbf{3 j}$}

2-(4-phenylthiazol-2-yl)acetonitrile (3a): M.p. $61^{\circ} \mathrm{C}$ $63^{\circ} \mathrm{C}$ (from $\mathrm{MeOH}$ ) (lit.[22], $62^{\circ} \mathrm{C}-63^{\circ} \mathrm{C}$; lit.[23], $60^{\circ} \mathrm{C}$ ).

2-[4-(4-chlorophenyl)thiazol-2-yl]acetonitrile (3b): M.p. $69^{\circ} \mathrm{C}-71^{\circ} \mathrm{C}$ (from $\mathrm{MeOH}$ ) (lit.[24], $69^{\circ} \mathrm{C}-70^{\circ} \mathrm{C}$ ).

2-[4-(4-fluorophenyl)thiazol-2-yl]acetonitrile (3c): M.p. $63^{\circ} \mathrm{C}-65^{\circ} \mathrm{C}$ (from $\mathrm{MeOH}$ ) (lit.[25], $64^{\circ} \mathrm{C}$ ).

2-(4-p-tolylthiazol-2-yl)acetonitrile (3d): M.p. $95^{\circ} \mathrm{C}$ $97^{\circ} \mathrm{C}$ (from $\mathrm{MeOH}$ ) (lit.[26], $97^{\circ} \mathrm{C}-98^{\circ} \mathrm{C}$ ).

2-[4-(4-methoxyphenyl)thiazol-2-yl]acetonitrile (3e): M.p. $59^{\circ} \mathrm{C}-61^{\circ} \mathrm{C}$ (from $\mathrm{MeOH}$ ) (lit.[23], not reported). (found $\mathrm{C}, 62.32 ; \mathrm{H}, 4.04 ; \mathrm{N}, 11.99 ; \mathrm{S}, 13.75 . \mathrm{C}_{12} \mathrm{H}_{10} \mathrm{~N}_{2} \mathrm{OS}$ requires $\mathrm{C}, 62.59 ; \mathrm{H}, 4.38 ; \mathrm{N}, 12.16 ; \mathrm{S}, 13.92 \%) \delta_{\mathrm{H}}(250$ $\left.\mathrm{MHz} ; \mathrm{CDCl}_{3}\right) 3.88$ (s, 3H, $\left.\mathrm{CH}_{3}\right), 4.20$ (s, 2H, $\mathrm{CH}_{2}$ ), 6.98 (dd, $2 \mathrm{H}, J=6.77,2.14 \mathrm{~Hz}, \mathrm{ArH}), 7.37$ (s, 1H, ArH), 7.84 (dd, 2H, $J=6.78,2.13 \mathrm{~Hz}, \mathrm{ArH})$.

2-[4-(4-hydroxyphenyl)thiazol-2-yl]acetonitrile (3f): M.p. $148^{\circ} \mathrm{C}-150^{\circ} \mathrm{C}$ (from $\mathrm{MeOH}$ ) (lit.[27], not reported), (found C, 60.88; H, 3.52; N, 12.66; S, 14.49. $\mathrm{C}_{11} \mathrm{H}_{8} \mathrm{~N}_{2} \mathrm{OS}$ requires $\mathrm{C}, 61.09 ; \mathrm{H}, 3.73 ; \mathrm{N}, 12.95 ; \mathrm{S}, 14.83 \%) \delta_{\mathrm{H}}(250$ $\left.\mathrm{MHz} ; \mathrm{CDCl}_{3}\right) 4.19$ (s, 2H, $\left.\mathrm{CH}_{2}\right), 6.92(\mathrm{dd}, 2 \mathrm{H}, J=6.66$, $2.17 \mathrm{~Hz}, \mathrm{ArH}), 7.36$ (s, 1H, ArH), 7.79 (dd, 2H, $J=6.66$, $2.16 \mathrm{~Hz}, \mathrm{ArH})$.

2-[4-(3-hydroxyphenyl)thiazol-2-yl]acetonitrile (3g): M.p. $118^{\circ} \mathrm{C}-120^{\circ} \mathrm{C}$ (from $\mathrm{MeOH}$ ), (found $\mathrm{C}, 60.76 ; \mathrm{H}$, $3.52 ; \mathrm{N}, 12.66 ; \mathrm{S}, 14.49 . \mathrm{C}_{11} \mathrm{H}_{8} \mathrm{~N}_{2} \mathrm{OS}$ requires $\mathrm{C}, 61.09$; $\mathrm{H}, 3.48 ; \mathrm{N}, 12.71 ; \mathrm{S}, 14.56 \%) \delta_{\mathrm{H}}\left(250 \mathrm{MHz} ; \mathrm{CDCl}_{3}\right) 4.21$ (s, 2H, $\mathrm{CH}_{2}$ ), 6.88 (dd, 1H, $\left.J=7.41,2.75 \mathrm{~Hz}, \mathrm{ArH}\right), 7.32$ (dd, $1 \mathrm{H}, J=6.99,1.21 \mathrm{~Hz}, \mathrm{ArH}), 7.42-7.46$ (m, 2H, ArH), 7.51 (s, 1H, ArH).

2-[4-(biphenyl-4-yl)thiazol-2-yl]acetonitrile (3h): $\mathrm{M}$. p. $113^{\circ} \mathrm{C}-115^{\circ} \mathrm{C}$ (from $\mathrm{MeOH}$ ) (lit.[27], not reported), (found $\mathrm{C}, 73.71 ; \mathrm{H}, 4.19 ; \mathrm{N}, 9.96 ; \mathrm{S}, 11.48 . \mathrm{C}_{17} \mathrm{H}_{12} \mathrm{~N}_{2} \mathrm{~S}$ requires $\mathrm{C}, 73.88 ; \mathrm{H}, 4.38 ; \mathrm{N}, 10.14 ; \mathrm{S}, 11.60 \%) \delta_{\mathrm{H}}(250$ $\left.\mathrm{MHz} ; \mathrm{CDCl}_{3}\right) 4.27$ (s, 2H, $\left.\mathrm{CH}_{2}\right), 7.48(\mathrm{~d}, 2 \mathrm{H}, J=7.39$ $\mathrm{Hz}, \mathrm{ArH}), 7.56$ (s, 1H, ArH), 7.65 - 7.72 (m, 5H, ArH), 7.99 (d, 2H, $J=8.59 \mathrm{~Hz}, \mathrm{ArH})$.

2-\{4-[4-(pyrrolidin-1-yl)phenyl]thiazol-2-yl\}acetoni trile (3i): M.p. $157^{\circ} \mathrm{C}-159^{\circ} \mathrm{C}$ (from $\mathrm{MeOH}$ ), (found $\mathrm{C}$, 66.67; H, 5.34; N, 15.39; $\mathrm{S}, 11.68 . \mathrm{C}_{15} \mathrm{H}_{15} \mathrm{~N}_{3} \mathrm{~S}$ requires $\mathrm{C}$, $66.88 ; \mathrm{H}, 5.61 ; \mathrm{N}, 15.60 ; \mathrm{S}, 11.90 \%) \delta_{\mathrm{H}}(200 \mathrm{MHz}$; $\left.\mathrm{CDCl}_{3}\right) 2.05\left(\mathrm{t}, 4 \mathrm{H}, J=13.18 \mathrm{~Hz}, \mathrm{CH}_{2} \mathrm{CH}_{2}\right), 3.37(\mathrm{t}, 4 \mathrm{H}$, $\left.J=12.75 \mathrm{~Hz}, \mathrm{CH}_{2} \mathrm{CH}_{2}\right), 4.17\left(\mathrm{~s}, 2 \mathrm{H}, \mathrm{CH}_{2}\right), 6.65$ (d, 2H, $J$ $=8.08 \mathrm{~Hz}, \mathrm{ArH}), 7.25(\mathrm{~d}, 1 \mathrm{H}, J=7.65 \mathrm{~Hz}, \mathrm{ArH}), 7.76(\mathrm{~d}$, $2 \mathrm{H}, J=8.93 \mathrm{~Hz}, \mathrm{ArH})$.

4-[2-(cyanomethyl)thiazol-4-yl]benzonitrile (3j): $\mathrm{M}$. p. $164^{\circ} \mathrm{C}-166^{\circ} \mathrm{C}$ (from $\mathrm{MeOH}$ ) (lit.[28], not reported), (found $\mathrm{C}, 63.81 ; \mathrm{H}, 2.85 ; \mathrm{N}, 18.11 ; \mathrm{S}, 13.87 . \mathrm{C}_{12} \mathrm{H}_{7} \mathrm{~N}_{3} \mathrm{~S}$ requires $\mathrm{C}, 63.98 ; \mathrm{H}, 3.13 ; \mathrm{N}, 18.65 ; \mathrm{S}, 14.23 \%) \delta_{\mathrm{H}}(250$ $\left.\mathrm{MHz} \mathrm{CDCl}_{3}\right) 4.21$ (s, 2H, $\mathrm{CH}_{2}$ ), 7.67 (s, 1H, $\left.\mathrm{ArH}\right), 7.75$ $(\mathrm{dd}, 2 \mathrm{H}, J=6.73,1.68 \mathrm{~Hz}, \mathrm{ArH}), 8.03(\mathrm{dd}, 2 \mathrm{H}, J=6.73$, $1.76 \mathrm{~Hz}, \mathrm{ArH})$.

\section{Results and Discussion}

The Hantzsch reaction remains one of the most reliable routes to thiazoles and it involves the reaction of a $\alpha$ bromomethylketone with a thioamide in refluxing ethanol or THF and treatment of the resulting thiazolyl hydrobromide with aqueous ammonia [29]. The reaction mechanism is well-known and described in the literature [30]. Different variants of this important approach have been reported and these include the use of a mixture of ethanol/DMF as solvent; addition of the $\alpha$-bromoketone dropwise, stirring the reaction mixture overnight at room temperature for 30 minutes - 45 minutes and then heating the mixture under reflux; pouring the reaction mixture 
into water and extracting the product with ethyl acetate or diethyl ether, instead of treatment with aqueous ammonia $[21,23,24,31]$. Another reported route provides 2-(cyanomethyl)thiazoles through the reaction of 2-sulfonylthiazoles with alkyl-2-cyanoacetates in the presence of a base, such as $\mathrm{NaH}$, in DMF to give 2-(thiazoly-2-yl)cyanoacetate esters, which were then hydrolyzed and decarboxylated [26]. Recently, new environmentally benign synthetic protocol for obtaining 2-amino-4-arylthiazoles employing microwave irradiation in water was reported. [32].

A literature survey revealed that the synthesis of 2cyanomethyl-4-phenylthiazoles from 2-cyanothioacetamide and substituted 2-bromoacetophenones under microwave irradiation has not been reported to date. The novel synthetic procedure to obtain substituted 2-cyanomethyl-4-phenylthiazoles involved the use of a Biotage microwave system (Initiatior 2.5) with focused microwave irradiation (Scheme 1).

We initially studied the progress of the reaction in polyethylene glycol 400 (PEG-400), which has been established as a green solvent due to a number of advantages, such as its wide availability at low cost and its low environmental impact [33]. Studies aimed at optimizing the cyclization reaction were carried out with 2-cyanothioacetamide (1) and 2-bromo-4'-chloroacetophenone (2b) (Table 1).

It was found that when the reaction was carried out in a closed vial in PEG-400, traces from the corresponding 2-[4-(4-chlorophenyl)thiazol-2-yl]acetamide were obtained along with the desired product in the reaction mixture (Table 1, entries 1 - 4). This observation was explained in terms of the presence of small amounts of water in the solvent and to the $\mathrm{HBr}$ generated as the reaction progressed. The formation of the amide as a by-product $(11 \%$ - 14\%) was proved by HPLC-MS on the reaction mixture. When the reaction was carried out in water as solvent the amide derivative was obtained as main product. These results led us to use an anhydrous solvent while keeping the aim for an environmentally sustainable synthetic procedure. The reaction was thus carried out in glycerol, which has even more advantages from an economic point of view (Table 1, entries 5, 8). Glycerol is more viscous than PEG-400 and for this reason both longer pre-stirring of the reaction mixture to obtain a good suspension and higher stirring rate during

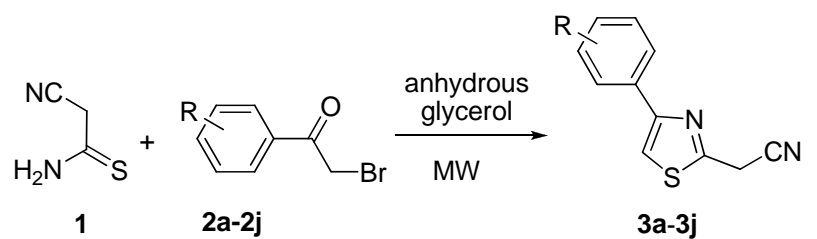

Scheme 1. Preparation of substituted 2-cyanomethyl-4phenylthiazoles under microwave. the reaction were necessary. In order to avoid the formation of the amide as by-product we decided to add 1 or 1.5 mole equivalents of triethylamine (TEA) or $\mathrm{N}, \mathrm{N}$ ethyldiiso-propyllamine (EDIPA) to the reaction mixture, but the presence of amide was also observed in these cases (Table 1, entires 7, 9, 10, 11, 12). Furthermore, when experiments with glycerol as solvent were performed, it was found that the temperature reached in the reaction mixture during the irradiation was a substantial factor that influenced the product yield and the presence of amide as by-product. Reactions carried out in glycerol at temperatures higher than $145^{\circ} \mathrm{C}-160^{\circ} \mathrm{C}$ also led to the formation of amide.

Finally, to avoid the presence of water-and therefore the formation of amide in the reaction mixture-anhydrous glycerol was used as solvent. The optimal temperature range was determined to be $95^{\circ} \mathrm{C}-120^{\circ} \mathrm{C}$ and this could be achieved when the reaction mixture was irradiated in the range 35 Watts - 40 Watts for a maximum 4 minutes - 4.5 minutes (Table 1, entries 15, 16). Irradiation at a power of 40 Watts for 4 minutes led to complete consumption of the starting materials (i.e., they were no longer detected by TLC) and this was considered

Table 1. Optimisation of reaction conditions for 2-cyanomethyl-4-(4-chlorophenyl) thiazole (3b).

\begin{tabular}{|c|c|c|c|c|}
\hline Entry & Solvent & $\begin{array}{c}\text { MW } \\
\text { [Watts] }\end{array}$ & $\begin{array}{l}\text { Irradiation } \\
\text { time [min] }\end{array}$ & $\begin{array}{c}\text { Product } \\
\text { yield [\%] }\end{array}$ \\
\hline 1 & PEG-400 & 50 & 1 & $55^{a}$ \\
\hline 2 & PEG-400 & 55 & 1.5 & $82^{a}$ \\
\hline 3 & PEG-400 & 60 & 1 & $69^{a}$ \\
\hline 4 & PEG-400 & 70 & 1 & $70^{a}$ \\
\hline 5 & glycerol & 70 & 1 & $68^{a}$ \\
\hline 6 & PEG-400 & 100 & 1 & overheated \\
\hline 7 & PEG-400 ${ }^{c}$ & 60 & 1 & $76^{a}$ \\
\hline 8 & glycerol & 55 & 1 & $74^{a}$ \\
\hline 9 & glycerol $^{c}$ & 55 & 1.5 & $79^{a}$ \\
\hline 10 & glycerol $^{d}$ & 60 & 1 & $65^{a}$ \\
\hline 11 & glycerol $^{e}$ & 60 & 1 & $71^{a}$ \\
\hline 12 & glycerol $^{f}$ & 60 & 1 & $70^{a}$ \\
\hline 13 & $\begin{array}{c}\text { anhydrous } \\
\text { glycerol }\end{array}$ & 60 & 1 & $84^{b}$ \\
\hline 14 & $\begin{array}{l}\text { anhydrous } \\
\text { glycerol }\end{array}$ & 40 & 2 & $74^{b}$ \\
\hline 15 & $\begin{array}{l}\text { anhydrous } \\
\text { glycerol }\end{array}$ & 40 & 3 & 78 \\
\hline 16 & $\begin{array}{l}\text { anhydrous } \\
\text { glycerol }\end{array}$ & 40 & 4 & 87 \\
\hline 17 & $\begin{array}{l}\text { anhydrous } \\
\text { glycerol }\end{array}$ & 35 & 3 & $71^{b}$ \\
\hline
\end{tabular}

apresence of 2-[4-(4-chlorophenyl)thiazol-2-yl]acetamide as by-product; ${ }^{b}$ presence of starting compound 2a; ${ }^{c}$ additional 1 mole equivalent of TEA; ${ }^{d}$ additional 1.5 mole equivalents of TEA; ${ }^{e}$ additional 1 mole equivalent of EDIPA; ${ }^{f}$ additional 1.5 mole equivalents of EDIPA. 
to represent the end of the reaction. Irradiation at a power lower than 35 - 40 Watts for time period between 1 minutes - 3 minutes did not lead to a high enough temperature for the two starting materials to react (Table 1, entries 14,17$)$ and irradiation at higher power led to decomposition (Table 1, entry 6).
The optimal conditions found for the cyclization of $\mathbf{1}$ with 2a were successfully applied to the reactions of 1a with differently substituted 2-bromoacetophenones $\mathbf{2 a - 2} \mathbf{j}$

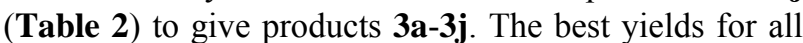
products were obtained when the reaction mixture wasirradiated at low power (40 Watts) for time intervals

Table 2. Starting materials, reaction conditions in anhydrous glycerol and isolated yield for products 3a-j.

\begin{tabular}{|c|c|c|c|c|}
\hline Starting material & Irradiation time [min] & MW [Watts] & Product & Yield/reported yield (\%) [ref] \\
\hline $\begin{array}{l}-\mathrm{COCH}_{2} \mathrm{Br} \\
\text { 2a }\end{array}$ & 3.5 & 40 & 3a & $\begin{array}{c}90 / 81[24], \\
87 \text { [29] }\end{array}$ \\
\hline 2b $\mathrm{COCH}_{2} \mathrm{Br}$ & 4 & 40 & 3b & $87 / 85[27]$ \\
\hline $\begin{array}{l}\text { - } \mathrm{COCH}_{2} \mathrm{Br} \\
\text { 2c }\end{array}$ & 4.5 & 40 & 3c & $79 / 60[25]$ \\
\hline 2d & 4.5 & 40 & 3d & $95 / 88[27]$ \\
\hline $2 e^{-\mathrm{COCH}_{2} \mathrm{Br}}$ & 4.5 & 40 & 3e & $\begin{array}{c}79 / 50 \\
{[29]}\end{array}$ \\
\hline 2f ${ }_{2} \mathrm{COCH}_{2} \mathrm{Br}$ & 4.5 & 40 & $3 f$ & $75 /[31]^{\mathrm{a}}$ \\
\hline $\begin{array}{l}-\mathrm{COCH}_{2} \mathrm{Br} \\
\mathbf{2 g}\end{array}$ & 3 & 45 & & 69 \\
\hline 2h $-\mathrm{COCH}_{2} \mathrm{~B}$ & 4 & 40 & 3h & 96 \\
\hline $2-\mathrm{COCH}_{2} \mathrm{Br}$ & 4.5 & 40 & $3 \mathbf{i}$ & 94 \\
\hline${ }_{\mathbf{2 j}} \mathrm{COCH}_{2} \mathrm{Br}$ & 4.5 & 40 & $3 \mathbf{j}$ & 85 \\
\hline
\end{tabular}

a yield not reported 
between 3.5 and 4.5 minutes (Table 2). "Blank" reactions in glycerol by conventional heating at $110^{\circ} \mathrm{C}-120^{\circ} \mathrm{C}$ for 4.5 minutes were carried out for products $3 \mathbf{b}$ and $3 \mathbf{h}$.

The reaction progress was monitored by TLC and in the samples from the reaction mixture by these conditions only traces of products were determined.

The majority of the synthesized compounds have been reported previously (Table 2).

The novel compounds and those that have not been fully described were characterized by ${ }^{1} \mathrm{H}-\mathrm{NMR}$ spectroscopy and by elemental analysis.

\section{Conclusions}

In conclusion, we carried out a highly effective and simple synthetic procedure to obtain 2-cyanomethyl-4-phenylthiazoles from different substituted 2-bromoacetophenones under microwave irradiation (Table 2). The method can be applied to the synthesis of a variety of 2-cyanomethyl-4-phenylthiazoles and gives products with high purity in short reaction times ( 3.5 minutes - 4.5 minutes). Minimal amounts of environmentally friendly solvents were used and the reaction procedure ensures easy isolation of the products.

\section{Acknowledgements}

The work was partly supported by the Bulgarian Scientific Research Fund under Grant DCVP 02/2-2009, Project "Union" and by the Spanish Ministerio de Ciencia e Innovacion (project CTQ2008-04313/BQU).

\section{References}

[1] N. Seko, K. Yoshino, K. Yokota and G. Tsukamoto, "Synthesis and Platelet Aggregation Inhibitory Activity of Diphenylazole Derivatives I. Thiazole and Imidazole Derivatives," Chemical \& Pharmaceutical Bulletin, Vol. 39, No. 3, 1991, pp. 651-657.

[2] C. S. Rooney, W. C. Randall, K. B. Streeter, C. Ziegler, E. J. Cragoe, H. Schwam, S. R. Michelson, H. W. R. Williams and E. Eichler, "Inhibitors of Glycolic Acid Oxidase. 4-Substituted 3-hydroxy-1H-pyrrole-2,5-dione Derivatives," Journal of Medicinal Chemistry, Vol. 26, No. 5, 1983, pp. 700-714. doi:10.1021/jm00359a015

[3] J. Crowforth, J. R. Atack, S. M. Cook, K. R. Gibson, A. Nadin, A. P. Owens, A. Pike, M. Rowley, A. J. Smith, B. Sohal, F. Sternfeld, K. Wafford and L. J. Street, "Tricyclic Pyridones as Functionally Selective Human GABAA Alpha 2/3 Receptor-Ion Channel Ligands," Bioorganic \& Medicinal Chemistry Letters, Vol. 14, No. 7, 2004, pp. 1679-1682. doi:10.1016/j.bmcl.2004.01.057

[4] A. Nadin and T. Harrison, "Synthesis of Tricyclic Pyridones by Radical Cyclization," Tetrahedron Letters, Vol. 40, No. 21, 1999, pp. 4073-4076.
doi:10.1016/S0040-4039(99)00652-8

[5] C. G. Caldwell, I. Kopka, M. L. Hammond and P. A. Zambias, "Substituted Thiazoles as Iimmunoregulants," US Patent No. 4746669, 1988.

[6] L. Elster, T. Hoegberg, A. Murray and J. M. Receveur, "Thiazole Derivatives as GPR 119 Modulators," WO No. 2010001166, 2010.

[7] I. Y. Choi, K. Lee, M. Chae, H. Kim, et all., "New Substituted 1,3-thiazole Derivatives or Pharmaceutically Acceptable Salts Thereof Having Immunosuppression and Inflammation Inhibitory Activity, Intermediate Compounds or Pharmaceutically Acceptable Salts thereof, a Process for the Preparation," WO No. 2006137658, 2006.

[8] E. V. Resnyanskaya, A. V. Tverdokhlebov, A. A. Tolmachev and Y. M. Volvenko, "Synthesis of 5-Amino-4(4-aryl-2-thiazolyl)-2,3-dihydro-2-pyrrolones," Russian Jour- nal of Organic Chemistry, Vol. 41, No. 2, 2005, pp. 257-260. doi:10.1007/s11178-005-0153-7

[9] M. H. Elnagdi, S. O. Abdallah, K. M. Ghoneim, E. M. Ebied and K. N. Kassab, "Synthesis of Some Coumarin Derivatives as Potential LaserDyes," Journal of Chemical Research, Synopses, No. 2, 1997, pp. 44-45. doi:10.1039/a603731c

[10] E. Hahn, G. Seybold and A. Stange, "Thiazolyl Cyanocoumarins and Their Use for the Areal Concentration of Light,” DE Patent No. 3609804, 1987.

[11] C. Vamvakaris, M. Patsch and W. Mach, "Thiazole Containing Coumarin Compounds," US Patent 440438, 1983.

[12] Ia. B. Kuziv, V. V. Ishchenko, V. P. Khilya and I. Y. Dubey, "Synthesis of Reagents Based on 7_Substituted 3 Thiazolylcoumarins for Covalent Labeling of Oligonucleotides," Ukrainica Bioorganica Acta, Vol. 6, No. 3, 2008, pp. 3-12.

[13] T. Deligeogiev, T. Tsvetkova, D. Ivanova and I. Timtcheva, "Synthesis and Electronic Spectra of 3-Hetaryl Substituted Coumarin Derivatives 7-Hydroxy-2H-chromen2-on and 9-hydroxy-2H-benzo(f)chromen-2-on", Color Technology, Vol. 124, No. 4, 2008, pp. 195-203. doi:10.1111/j.1478-4408.2008.00141.x

[14] A. Schwartz, Z. Pal, L. Szabo, K. Simon, I. Hermecz and Z. Meszaros, "Nitrogen Bridgehead Compounds, Part $68^{ \pm}$. Studies on Quinolizine Derivatives. Part 2. Synthesis of 1,3-Disubstituted-4H-quinolizine Derivatives," Journal of Heterocyclic Chemistry, Vol. 24, No. 3, 1987, pp. 645650. doi:10.1002/jhet.5570240320

[15] G. H. Elgemeie and N. H. Metwally, "Synthesis of Structurally Related Purines: Benzimidazo[1,2-a]pyridines, Benzimidazo-[1,2-c]pyrimidines, and Pyrazolo-[1,5-a] pyrimidines," Monatshefte für Chemie, Vol. 131, No. 7, 2000 , p. 779. doi:10.1007/s007060050025

[16] E. N. Ulomskii, S. L. Deev, V. L. Rusinov and O. N. Chupakhin, "Synthesis of Benzimidazolylazolo[5,1-c][1,2,4] triazines," Russian Journal of Organic Chemistry, Vol. 35, No. 9, 1999, pp. 1355-1362.

[17] J. V. Metzger, "Comprehensive Heterocyclic Chemistry," In: A. R. Katritzky and C. W. Rees, Eds., Pergamon, Oxford, 1984. 
[18] H. Singh, S. Singh and A. S. Cheema, "Intermediates in Hantzsch Synthesis and Synthesis of Symmetrical Thioethers," Journal of the Indian Chemical Society, Vol. 53, No. 7, 1975, p. 682.

[19] P. Knochel, "Modern Solvents in Organic Synthesis," Springer, Heidelberg, 1999. doi:10.1007/3-540-48664-X

[20] Y. Gu, J. Barrault and F. Jerrome, "Glycerol as an Efficient Promoting Medium for Organic Reactions," $A d$ vanced Synthesis \& Catalysis, Vol. 350, No. 13, 2008, pp. 2007-2012. doi:10.1002/adsc.200800328

[21] A. Wolfson, G. Litvak, C. Dlugy, Y. Shotland and D. Tavor, "Employing Crude Glycerol from Biodiesel Production as an Alternative Green Reaction Medium," Industrial Crops and Products, Vol. 30, No. 1, 2009, pp. 78-81. doi:10.1016/j.indcrop.2009.01.008

[22] H. Schäffer and K. Gewald, "Zur Chemie des 4-Phenylthiazoly-(2)-acetonitrils, " Journal für Praktische Chemie, Vol. 316, No. 4, 1974, pp. 684-692. doi:10.1002/prac.19743160421

[23] E. Menta, G. Da Re and M. Grungi, "Derivatives of Chromen-2-one as Inhibitors of Vegf Production in Mammalian Cells," US Patent No. 20060122387, 2006.

[24] Imperial Chemical Industries, Neth. Appl. 6614130, 1968.

[25] Y. M. Volovenko, E. V. Resnyanska and A. V. Tverdokhlebov, "A Facile Route to the 6-Hetaryl Substituted Pyrrolo[1,2-a] thieno[3,2-e]pyrimidine Derivatives," Collection of Czechoslovak Chemical Communications, Vol. 67, No. 3, 2002, pp. 365-372. doi:10.1135/cccc20020365

[26] T. Yakihara, S. Okuchi and M. Hatano, "2-(Thiazol-2-yl) cyanoacetic Acid Ester Derivative and Method for Producing the Same," Kokai Tokkyo Koho, JP Patent No. 200-
2249486, 2002.

[27] V. D. Dyachenko, T. A. Rilskaya and S. V. Savchuk, "Cross-Recyclization of 4-Aryl-2,6-diamino-3,5-dicyano4H-thiopyranes with Alkylations Reagents," Kharkov University Bulletin, Vol. 731, No. 14, 2006, pp. 86-89.

[28] P. Gaillard, J.-P. Gottenland, I. Jeanclaude-Etter, M. Schwarz and R. J. Thomas, "Azole Methylident Cyanide Deriwatives and Their Use as Protein Kinase Modulators," WO No. 2003106455, 2003.

[29] Y. M. Volovenko, A. V. Tverdokhlebov, A. P. Gorulya, S. V. Shishkina, R. I. Zubatyuk and O. V. Shishkin, "A New and Convenient Synthesis of 1,2-Diamino-3-hetarylpyrrole Derivatives," European Journal of Organic Chemistry, Vol. 2002, No. 4, 2002, pp. 663-668. doi:10.1002/1099-0690(200202)2002:4<663::AID-EJOC $663>3.0 . \mathrm{CO} ; 2-\mathrm{A}$

[30] A. W. Erian, S. M. Sherif and H. M. Gaber, "The Chemistry of $\alpha$-Haloketones and Their Utility in Heterocyclic Synthesis," Molecules, Vol. 8, No. 11, 2003, pp. 793-865. doi: $10.3390 / 81100793$

[31] E. Menta, G. Da Re and M. Grungi, "Derivatives of Chromen-2-one as Inhibitors of VEGF Production in Mammalian Cells," WO No. 2003105842, 2003.

[32] K. Jain, J. Bariwal, M. Kathiravan, V. Raskar, G. Wankhede, N. Lonhe and S. Dighe, "An Efficient and Rapid Synthesis of 2-Amino-4-Arylthiazoles Employing Microwave Irradiation in Water," Green and Sustainable Chemistry, Vol. 1, No. 2, 2011, pp. 36-40.

[33] J. Chen, S. K. Spear, J. G. Huddleston and R. D. Rogers, "Polyethylene Glycol and Solutions of Polyethylene Glycol as Green Reaction Media," Green Chemistry, Vol. 7, No. 2, 2005, pp. 64-82. doi:10.1039/b413546f 